\title{
Optimization of Water Requirement in Maize (Zea mays L) under Different Irrigations
}

\author{
Shaloo $^{1 *}$, R. Kaur ${ }^{1}$, Man Singh ${ }^{1}$ and Sapna ${ }^{2}$ \\ ${ }^{1}$ ICAR-Indian Agricultural Research Institute, ${ }^{2}$ ICAR-National Bureau of Plant Genetic \\ Resources, New Delhi, India \\ *Corresponding author
}

\section{A B S T R A C T}

\begin{tabular}{|l|}
\hline Ke y w or d s \\
$\begin{array}{l}\text { SMD, Water } \\
\text { requirement, Water } \\
\text { applied and Water } \\
\text { use efficiency } \\
\text { (WUE) }\end{array}$ \\
\hline Article Info \\
\hline $\begin{array}{l}\text { Accepted: } \\
\text { 07 October 2020 } \\
\text { Available Online: } \\
\text { 10 February } 2021\end{array}$ \\
\hline \hline
\end{tabular}

\begin{abstract}
Due to overexploitation of available water resources, it has become very important to develop new technologies and methods of irrigation that can be helpful to utilize this precious input in an effective way. An experiment was conducted to determine water requirement and response of maize varietiesVIVEK QPM-9, PEEHM-5, HQPM-1 and HQPM-5 to irrigation at 50\% soil moisture depletion (SMD) level. Moisture contents were recorded from a root zone of $90 \mathrm{~cm}$ (from five depths viz., 0 - 15, $15-30,30-45,45-$ 60 and $60-90 \mathrm{~cm}$ ) for irrigation. Data on climatic parameters was also recorded for the growing period. The results indicated thatyield was significantly affected by no. of irrigations as well as varieties. All the varieties gave significant response up to two irrigations (I2) only. The total amount of water applied up to two irrigation was $50.7 \mathrm{~cm}$ including effective rainfall. The yield obtained at irrigation level (I2) for variety VIVEK QPM-9, PEEHM-5, HQPM-1 and HQPM-5 is 5.5t/ha,5.2t/ha, $6.3 \mathrm{t} / \mathrm{ha}$ and $5.8 \mathrm{t} / \mathrm{ha}$, respectively.
\end{abstract}

\section{Introduction}

Maize (Zea mays L) is one of the most versatile emerging crops having wider adaptability under varied agro-climatic conditions. In India, maize is the third most important food crop after rice and wheat. Considerable amounts of water diverted for irrigation are not effectively used for crop production (FAO, 1992). Therefore, the great challenge facing the agricultural sector is to produce more food from less water by increasing crop water productivity (Kijne et al., 2003). Crop water requirement is the measure of the amount of water required for evapotranspiration, when sufficient soil water is maintained by precipitation and/or irrigation so that it doesn't restrain plant development and yield (Djaman et al., 2017). The amount of water required for maize (or any other crop) depends on the duration of growth and development stages of the crop, the evaporative demand of the environment, and expansion of canopy, crop species and planting density (Wright and Bell, 1992). Water use for a crop can be estimated if water supplied by rainfall and/or irrigation, the amount used by the crop in 
evapotranspiration, the change in soil moisture storage and the amount lost by deep percolation are known (Olasantan, 2008).To improve efficiency of water use in irrigated agriculture, a comprehensive knowledge of crop water requirement, critical crop growth stages, and irrigation schedules for maximizing production are highly desirable along with the availability of adequate amount of water to meet the crop requirement (Kang et al., 2003). Udom and Kamalu (2019) reported that the seasonal water use of maize crop depends on planting and harvesting dates.

Knowledge of precise amount of water required by different crops in a given climatic condition of a region will be helpful in planning of irrigation scheme, irrigation scheduling and management of irrigation system. There is need to save irrigation water by providing minimum no. of irrigations without affecting yield by carrying out practices of irrigation water management to achieve higher water use efficiency (WUE). Therefore, keeping this in view, the present study was conducted to determine water requirement and response of maize varieties to different no. of irrigations at 50\% SMD.

\section{Materials and Methods}

\section{Experimental details}

The experiment was arranged in split plot design with three replications. Four maize varieties viz.VIVEK QPM-9(V1), PEEHM5(V2), HQPM-1(V3) and HQPM-5(V4) were plantedduring kharif season of 2013 in a sandy loam soil at research farm of Water Technology Centre, IARI, New Delhi to determining the water requirement. Irrigation treatment consists of (I1-one irrigation), (I2two irrigations) and(I3-three irrigations) based on $50 \%$ soil moisture depletion(SMD).

\section{Soil sampling and laboratory analysis}

The amount of water applied to each treatment was calculated on the basis of the soil moisture contents at the time of irrigation. SMD was determined by estimating soil moisture content. For this purpose, soil samples were taken from the effective rootzone divided into five sections viz., 0-15, 15$30,30-45,45-60$ and 60-90 cm.

Soil samples were collected from these five sections and fresh weight of the soil sampled was immediately recorded with the help of weighing balance. After weighing, the samples were stored in tin pans which were then placed in an electric oven for $24 \mathrm{~h}$ at $100^{\circ} \mathrm{C}$ and dry weight of the samples were then recorded. Soil moisture contents were then calculated as under

Soil moisture content $(96)=\frac{\text { Dryweight of the sample }}{\text { Freshweight of the sample }} \otimes 100$

The amount of water applied to each treatment was calculated on the basis of the soil moisture contents at the time of irrigation by using the following expression.

\section{$\mathrm{d}=\mathrm{M} \cdot \mathrm{C} \times \mathrm{B} . \mathrm{D} \times \mathrm{D}$}

Where, $\mathrm{d}$ is the depth of water to be applied, M.C is the moisture content (\%), B.D. is bulk density of the soil and $\mathrm{D}$ is depth of root-zone to be irrigated.

Water use efficiency was also calculated as the ratio of grain yield and water applied.

WUE $=$ Yield/Total water applied

Data on meteorological parameters like temperature and rainfall were also recorded during the period. Rainfall during the growing period is shown in Fig.1. 


\section{Data analysis}

The statistical analysis was performed by using OPSTAT software (Sheoran et al., 1998) for different no of irrigations and yield for estimation of analysis of variance (ANOVA) at a probability level of 0.05 .

\section{Results and Discussion}

The total amount of water applied up to two irrigation was $50.7 \mathrm{~cm}$ including pre-sowing irrigation and the observed yield for varietyVIVEK QPM-9, PEEHM-5, HQPM-1 and HQPM-5 is $5.5 \mathrm{t} / \mathrm{ha}, 5.2 \mathrm{t} / \mathrm{ha}, 6.3 \mathrm{t} / \mathrm{ha}$ and $5.8 \mathrm{t} / \mathrm{ha}$, respectively. The water use efficiency for varieties VIVEK QPM-9, PEEHM-5, HQPM-1 and HQPM-5 was 109 $\mathrm{kg} / \mathrm{ha} . \mathrm{cm}, 104 \mathrm{~kg} / \mathrm{ha} . \mathrm{cm}, 125 \mathrm{~kg} / \mathrm{ha} . \mathrm{cm}$ and $115 \mathrm{~kg} / \mathrm{ha} . \mathrm{cm}$, respectively. Total water applied during the growing period, WUE and grain yield of maize varieties are presented in Table 1 and effect of varying levels of irrigation on grain yield is shown in Table 2. The result indicated that there was significant difference among variety means. Yield was significantly affected by irrigation treatments. The interactive effect of variety and irrigation treatment was not significant.All the varieties gave significant response upto two irrigations (I2) only.

Table.1 Total water applied during the growing period, WUE and Grain Yield of Maize Varieties

\begin{tabular}{|l|l|l|l|l|l|l|l|l|l|l|l|}
\hline \multicolumn{2}{|c|}{ Grain Yield(q/ha) } & $\begin{array}{l}\text { Water } \\
\text { applied } \\
\text { (cm) }\end{array}$ & $\begin{array}{l}\text { ER } \\
\text { (cm) }\end{array}$ & $\begin{array}{l}\text { Total } \\
\text { water } \\
\text { applied } \\
\text { (cm) }\end{array}$ & \multicolumn{2}{|l|}{ WUE(kg/ha.cm) } & & $\begin{array}{l}\text { No. } \\
\text { Irrigations } \\
\text { of } \\
\text { SM\% }\end{array}$ \\
\hline V1 & V2 & V3 & V4 & & & & V1 & V2 & V3 & V4 & \\
\hline 51.4 & 48.6 & 56.8 & 52.7 & 11.3 & 34.1 & 45.4 & 113 & 107 & 125 & 116 & I1 \\
\hline 55.1 & 52.5 & 63.6 & 58.1 & 16.6 & 34.1 & 50.7 & 109 & 104 & 125 & 115 & I2 \\
\hline 54.7 & 50.4 & 59.1 & 59.3 & 21.9 & 34.1 & 56 & 98 & 90 & 106 & 106 & I3 \\
\hline
\end{tabular}

Table.2 Effect of irrigation on grain yield of different Maize varieties

\begin{tabular}{|l|c|c|c|c|}
\hline & $\mathbf{1 1}$ & $\mathbf{I 2}$ & $\mathbf{I 3}$ & Mean (V) \\
\hline VIVEK QPM-9(V1) & 51.4 & 55.1 & 54.7 & 53.7 \\
\hline PEEHM-5(V2) & 48.6 & 52.5 & 50.4 & 50.5 \\
\hline HQPM-1(V3) & 56.8 & 63.6 & 59.1 & 59.8 \\
\hline HQPM-5(V4) & 52.7 & 58.1 & 59.3 & 56.7 \\
\hline Mean (I) & 52.4 & 57.3 & 55.9 & \\
\hline Factors & & C.D. at 5 \% & SE(d) & SE(m) \\
\hline Factor(V) & & 5.0 & 2.0 & 1.4 \\
\hline Factor(I) & 3.4 & 1.6 & 1.1 \\
\hline Factor(I)at same level of V & NS & 3.2 & 2.4 \\
\hline Factor(V)at same level of I & NS & 0.0 & 0.0 \\
\hline
\end{tabular}


Fig.1 Rainfall during growing period

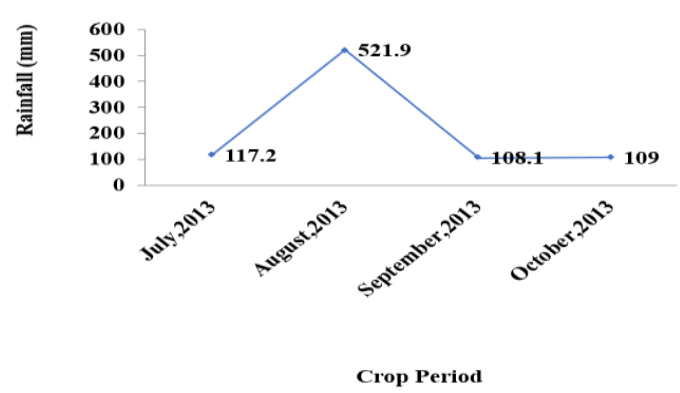

Fig.2 Water production function for maize

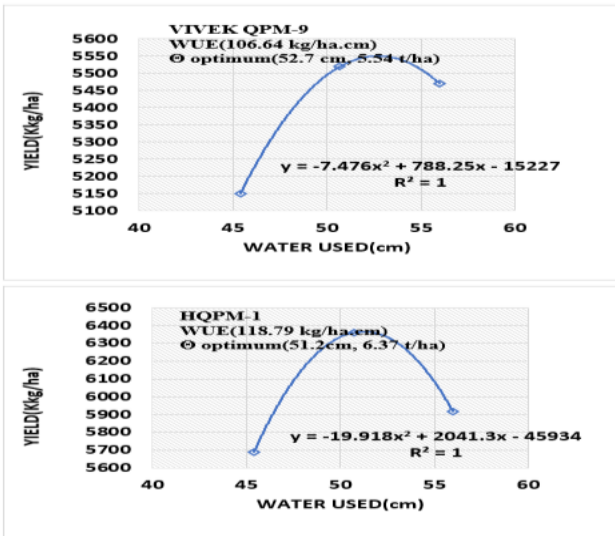

From water production function as shown in Fig.2 it was observed that the optimum water productivity of variety VIVEK QPM-9 is 52.7 $\mathrm{cm}$ and the corresponding yield and WUE was $5.5 \mathrm{t} / \mathrm{ha}$ and $106.64 \mathrm{~kg} / \mathrm{ha} . \mathrm{cm}$. The optimum water productivity of PEEHM-5 is $51.4 \mathrm{~cm}$ and the corresponding yield and WUE was $5.2 \mathrm{t} / \mathrm{ha}$ and $100.3 \mathrm{~kg} / \mathrm{ha} . \mathrm{cm}$ whereas, in case of HQPM-1 and HQPM-5 observed optimum water productivity was $51.2 \mathrm{~cm}$ and $54.9 \mathrm{~cm}$ and the corresponding yield was $6.3 \mathrm{t} / \mathrm{ha}$ and $5.9 \mathrm{t} / \mathrm{ha}$. The WUE for variety HQPM-1 and HQPM-5 was 118.79 $\mathrm{kg} / \mathrm{ha} . \mathrm{cm}$ and $112.3 \mathrm{~kg} / \mathrm{ha} . \mathrm{cm}$, respectively.

In the present study, water requirement of four maize varieties was estimated by conducting field experiment and it was observed that there was significant difference among variety means and the interactive

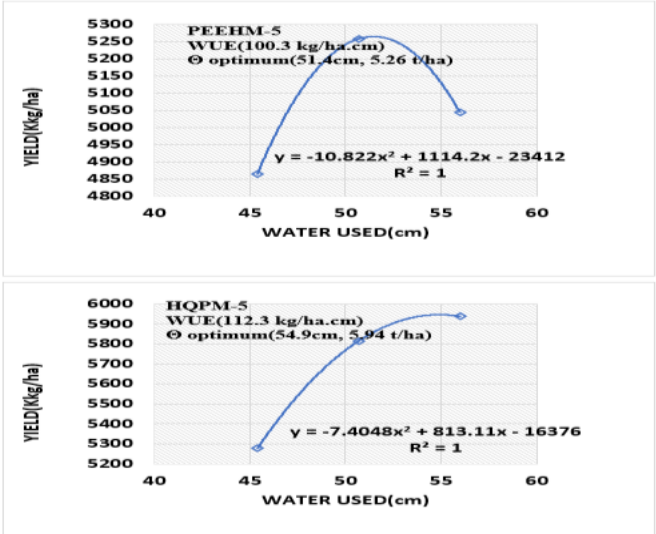

effect of variety and irrigation treatments were not found significant whereas, yield was significantly affected by irrigation treatments.

\section{References}

Bassey E. Udom and Onyinyechi J. Kamalu (2019). Crop Water Requirements during Growth Period of Maize (Zea mays L.) in a Moderate Permeability Soil on

Coastal Plain Sands. International Journal of Plant Research 2019, 9(1): 1-7.DOI: 10.5923/j.plant.20190901.01

Djaman, K., Mel, V. C., Balde, A. B., Bado, B. V., Diop, L., Manneh, B., Mutiibwa, D., Rudnick, D., Irmak, S. and Futakuchi, K. (2017). Evapotranspiration, irrigation water requirement and water productivity of 
rice (Oryza sativa L.) in the Sahelian Environment. Paddy and Water Environment 15: 469-482.

FAO (1992). Expert Consultation on Revision of FAO Methodologies for Crop Water Requirements. FAO, Rome, p. 60.

Kijne JW, Barker R, Molden D (2003). Water Productivity in Agriculture: Limits and Opportunities for Improvement. CAB International, Wallingford, UK. p.368.

Kang Shaozhong, Gu Binjie, Du Taisheng, Zhang Jianhua (2003). Crop Coefficient and Ratio of Transpiration to Evapotranspiration of Winter Wheat and Maize in A Semi-humid Region. Agric. Water Manag. 59: 239-254.

Olasantan, F. O. (2008). The effect of soil temperature andmoisture content on crop growth and yield of intercropping maize and yam. Exp. Agric. 24: 67-74.

Sheoran, O.P, Tonk, D.S, Kaushik, L.S, Hasija, R.C. and Pannu, R.S. (1998). Statistical software package for agricultural research workers. Recent advances in information theory, statistics \& computer applications by D.S. Hooda\&R.C.Hasija Department of mathematics statistics, CCS HAU, Hisar (139-143).

Wright, G. C. and Bell, M. F. (1992). Plant population studies on groundnut (Arachis hypogaea L.) in subtropical Australia 3:

Growth and water use during a terminal draught stress. Aust. J. Exp. Agric. 32: 197-203.

\section{How to cite this article:}

Shaloo, R. Kaur, Man Singh and Sapna. 2021. Optimization of Water Requirement in Maize (Zea mays L) under Different Irrigations. Int.J.Curr.Microbiol.App.Sci. 10(02): 638-642. doi: https://doi.org/10.20546/ijcmas.2021.1002.076 